İsletme Bilimi Dergisi 2020

Cilt:8 Sayı:3
SAKARYA

ÜNIVERSITESI
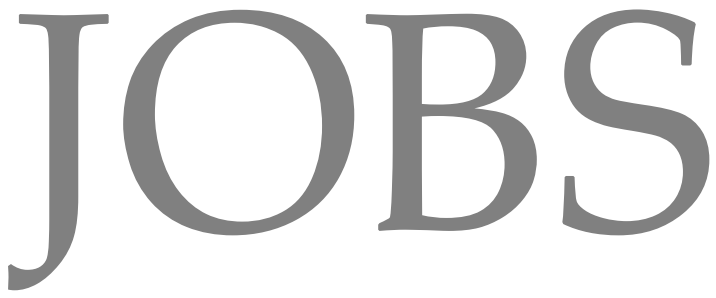

İşletme Bilimi Dergisi

The Journal of Business Science

Sakarya Üniversitesi / Sakarya University İşletme Fakültesi / Sakarya Business School

$\begin{array}{ll}\text { Cilt/Volume } & : 8 \\ \text { Say1/Issue } & : 3 \\ \text { Yil/Year } & : 2020\end{array}$

ISSN: 2148-0737

DOI: $10.22139 /$ jobs 
İşletme Bilimi Dergisi 2020 Cilt:8 Sayı:3 İNDEKS BILGILERİ/ INDEXING INFORMATION
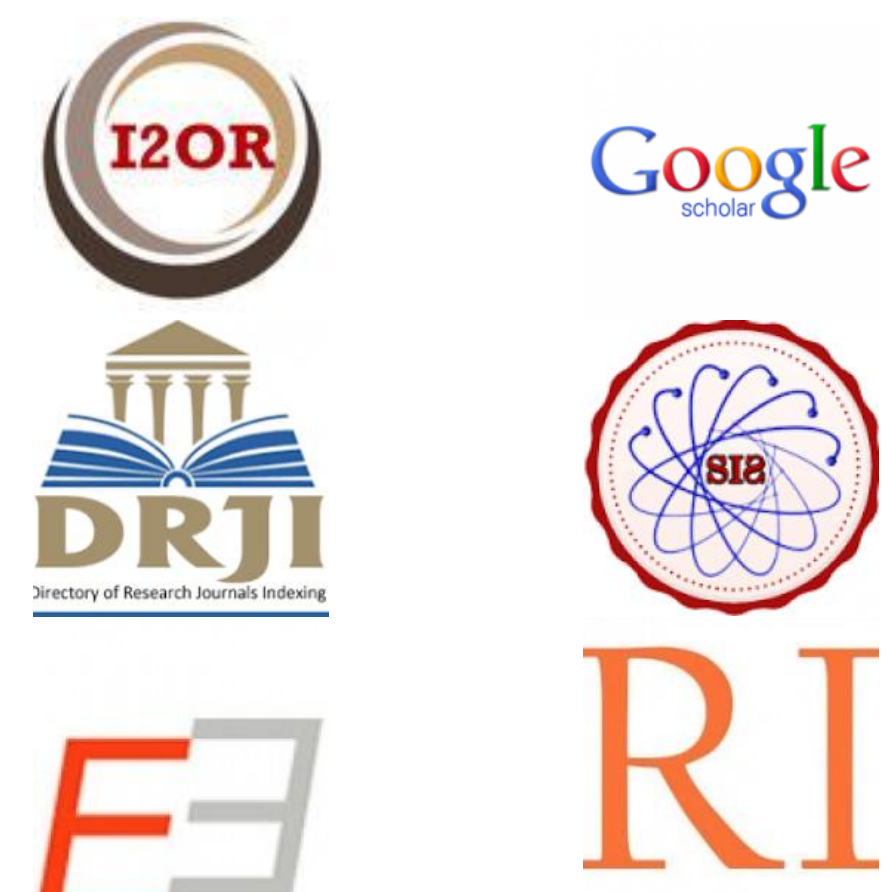

ii

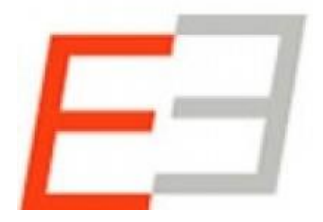

Akademik Arasstrumadar Indeksi
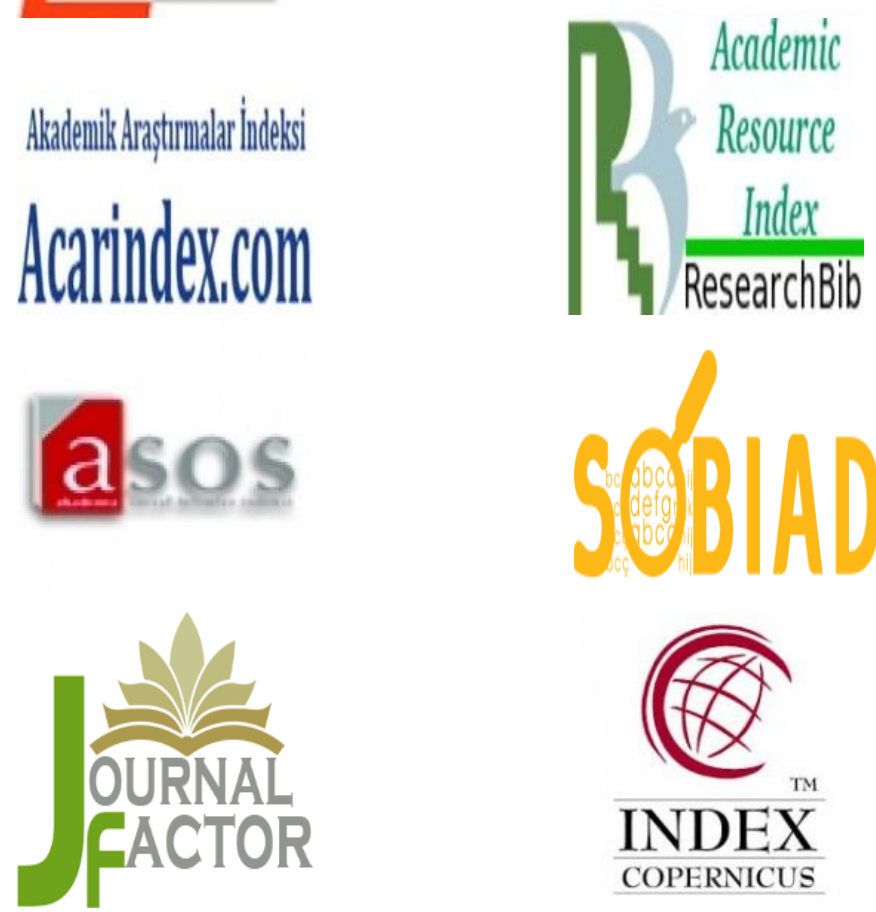
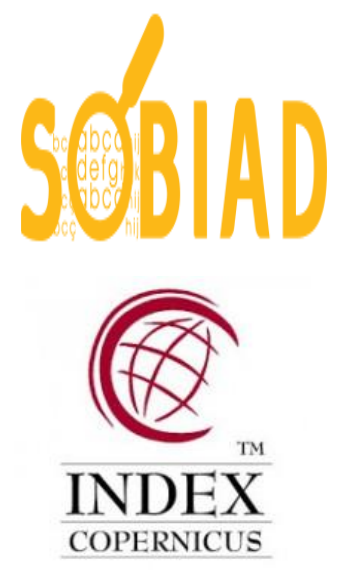
Kurucu Sahip/Founder

Prof. Dr. Gültekin YILDIZ

Imtiyaz Sahibi / Owner

Prof. Dr. Kadir ARDIÇ

Editör / Editor

Prof. Dr. Mahmut AKBOLAT

Editör Yardımcıları / Assoc. Editors

Prof. Dr. Mustafa Cahit UNGAN

Arş. Gör. Dr. Özgün ÜNAL

Mizanpaj Editörü / Layout Editor

Arş. Gör. Mustafa AMARAT
Issletme Bilimi Dergisi

2020

Cilt:8 Sayı:3

\section{DanışmaKurulu/Advisory Board}

Prof. Dr. Ahmet Vecdi CAN

Prof. Dr. Bülent SEZEN

Prof. Dr. Dilaver TENGİLIMOĞLU

Prof. Dr. Erman COŞKUN

Prof. Dr. Kadir ARDIÇ

Prof. Dr. Mehmet BARCA

Prof. Dr. Neşet HİKMET

Prof. Dr. Nihat ERDOĞMUŞ

Prof. Dr. Orhan BATMAN

Prof. Dr. Recai COŞKUN

Prof. Dr. Remzi ALTUNIŞIK

Prof. Dr. Selahattin KARABINAR

Prof. Dr. Sidıka KAYA

Prof. Dr. Şevki ÖZGENER

Prof. Dr. Türker BAŞ

Doç. Dr. Surendranath Rakesh JORY
Sakarya Üniversitesi

Gebze Yüksek Teknoloji Enstitüsü

Atılım Üniversitesi

İzmir Bakırçay Üniversitesi

Sakarya Üniversitesi

Ankara Sosyal Bilimler Üniversitesi

South Carolina Üniversitesi

İstanbul Şehir Üniversitesi

Sakarya Üniversitesi

İzmir Bakırçay Üniversitesi

Sakarya Üniversitesi

İstanbul Üniversitesi

Hacettepe Üniversitesi

Nevşehir Üniversitesi

Galatasaray Üniversitesi

Southampton Üniversitesi 
İşletme Bilimi Dergisi

2020

Cilt:8 Sayı:3

It is assumed that the articles submitted for publication in our journal are written in ethical principles and the authors have obtained the necessary legal approvals from the relevant ethics committee. The responsibility of this matter belongs to the authors. Scientific responsibility for the articles belongs to the authors themselves. Published articles could be cited in other publications provided thatfullreferenceisgiven.

İşletme Bilimi Dergisi; www.dergipark.gov.tr/jobs SakaryaÜniversitesi İsletme Fakültesi jobs@sakarya.edu.tr Esentepe Kampüsü 54187 Serdivan/SAKARYA 


\section{Bu Sayıda Katkıda Bulunan Hakemler} Reviewers List of This Issue
İsletme Bilimi Dergisi 2020

Cilt:8 Sayı:3
Prof. Dr. Burhanettin ZENGİN

Prof. Dr. Semra BORAN

Doç. Dr. Aydın YILMAZER

Doç. Dr. Emrah ÖZSOY

Doç. Dr. Samet GÜNER

Doç. Dr. Sema POLATÇI

Doç. Dr. Sema YİĞİT

Doç. Dr. Vahit YİĞİT

Dr. Öğr. Üyesi Ahmet KAR

Dr. Öğr. Üyesi Emre ORUÇ

Dr. Öğr. Üyesi Ersin IRK

Dr. Öğr. Üyesi Fatih BUDAK

Dr. Öğr. Üyesi Muhammet CANKAYA

Dr. Öğr. Üyesi Musa Said DÖVEN

Dr. Öğr. Üyesi Mustafa YILDIRIM

Dr. Öğr. Üyesi Nurperihan TOSUN

Dr. Öğr. Üyesi Oğuzhan ÖZTÜRK

Dr. Öğr. Üyesi Rojan GÜMÜŞ

Dr. Öğr. Üyesi Sedat DURMUŞKAYA

Dr. Öğr. Üyesi Serkan DENIZ

Dr. Öğr. Üyesi Serap TAŞKAYA

Dr. Elif Elçin GÜNAY

Dr. Mustafa KOÇ
Sakarya Uygulamalı Bilimler Üniversitesi Sakarya Üniversitesi

Sakarya Uygulamalı Bilimler Üniversitesi Sakarya Üniversitesi

Sakarya Üniversitesi

Tokat Gaziosmanpaşa Üniversitesi

Ordu Üniversitesi

Süleyman Demirel Üniversitesi

Kırıkkale Üniversitesi

Bilecik Şeyh Edebali Üniversitesi

Tokat Gaziosmanpaşa Üniversitesi

Kilis 7 Aralik Üniversitesi

Hitit Üniversitesi

Eskişehir Osmangazi Üniversitesi

Sakarya Üniversitesi

Sivas Cumhuriyet Üniversitesi

İzmir Bakırçay Üniversitesi

Dicle Üniversitesi

Sakarya Uygulamalı Bilimler Üniversitesi Yalova Üniversitesi

Osmaniye Korkut Ata Üniversitesi

Sakarya Üniversitesi

Sakarya Üniversitesi 
Değerli Bilim İnsanları,

İşletme Bilimi Dergisinin 8. Cilt 3. Sayısı ile sizlerin huzurunda olmaktan gurur duyuyoruz. İşletme Bilimi Dergisi olarak faaliyete başladığımı ilk günden bu yana İşletme Biliminin farklı disiplerinden yayınlar ile hazırlanmış, zengin içerikler ile alana katkı sağlama gayesindeyiz. Bu sayımızda da yayınlanan 7 makalemiz ile bu gayemizi gerçekleştirmenin mutluluğunu hissediyoruz.

Sayımizin ilk makalesi Murat NAZLI ve Hande ARBAK tarafindan hazırlanan "Hastanelerde să̆lik hizmetleri hakkındaki e-şikayetlerin stratejik önemi" başlıklı makaledir. Makalede sağlık endüstrisindeki hastaların eşikayetlerinin stratejik önemini anlamak ve analiz etmek amaçlanmaktadır. Ortaya koyduğu sonuçlar bakımından sağlık yöneticilerin önemli doneler sunan makalenin alana katkı să̆layacı̆̆ını düşünmekteyiz.

Sayımızın ikinci makalesi Ferda ALPER AY ve Canan UÇAR YENIHAYAT kaleminden çıkan "112 acil sağlık çalışanlarının hasta güvenliği kültürü̈ algılarının incelenmesi" başlıkl makaledir. Makalede günümüzün önemli konularından olan hasta güvenliği hakkkında 112 acil servis çalışanlarının algılarmın bazı sosyodemografik özelliklere göre farklılık gösterip göstermediŏi araştılmıştır. Makalenin Sağlık Yönetimi alanına katkı sağlayacă̆ına inanmaktayız.

Sayımızın bir diğer makalesi Sibel SATICI, Recep SATICI ve Burcu ÖZCAN'ın hazırlamış olduğu, programlanabilir güç kaynă̆ı cihazının ölçüm yeterliliğinin analiz edilmesi amaçlanan, "Programlanabilir güç cihazının ölçüm yeterliliğinin GAGE RER ile analiz edilmesi" başlıkl makaledir. Makalenin ortaya koymuş olduğu sonuçlarm e ölçüm sisteminin yeterliliğinin belirlenmesinin kalite iyileştirme çalışmaları için önemli bir unsur olması nedeniyle alana ve uygulamaya katkı sağlayacă̆ını düşünmekteyiz.

Ercan TAŞKIN, H. Yelda ŞENER ve Betül BILLGIÇ tarafindan hazırlanan "Eskişehir destinasyon markasının geliştirilmesinde lületaşı" başlıklı makalemiz Eskişehir destinasyon markasının geliştirilmesine yönelik olarak lületaşı işlemeciliğini; eğitim, ürün tasarımı, tanıtım, destinasyon marka imajına ve şehrin ekonomisine katkısı bakımından durum değerlendirmesi, sorun tespiti ve öneriler sunmak amacıyla hazırlanmıştır. Turizm alanına katkı sağlayacă̆ını düşündü̈̆̈̈̈müz makalemizin sonuçları oldukça ilgi çekicidir.

Sayımızın beşinci makalesi Güler SAĞLAM ARI, Nuray GÜNERI TOSUNOĞLU ve Berrin FİLIZÖZ tarafindan kaleme alınan; örtük liderlik teorileri çerçevesinde kadınların ve erkeklerin zihinlerindeki lider ve kadın lider prototiplerini ortaya koymayı amaçlamayan "Yönetici bir kadın ise lider prototipi farklılaşır mı?" başlıklı makalemizdir. Çalışmada lider olarak seçilme ve etkili bulunmada kritik olan örtük liderlik teorilerinin açıklanması, Türkiye'de kadınların karşı karşıya kaldıkları
Işletme Bilimi Dergisi

2020

Cilt:8 Sayı:3 
İşletme Bilimi Dergisi 2020 Cilt:8 Sayı:3

ii

zihinsel kalıpları görmek açısından önem arz ettiğine inanmaktayız.

Sayımızda yer alan bir diğger makalede Dursun KELEŞ ve Abitter ÖZULUCAN havayolu işletmelerinin finansal performanslarmın rasyo yöntemi ile analiz edilerek sonuçların ortaya konulmasını amaçlamaktadır. "Havacılık işletmelerinde Rasyo yöntemi ile finansal performans ölçümü: Borsa İstanbul (BISST)'da işlem gören iki havayolu işletmesi üzerine bir araştırma" başlıklı bu makalemizin havayolu işletmeleri yöneticilerinin ve diğer finansal bilgi kullanıcıların alacakları kararların sağlıklı olabilmesi için, havayolu işletmelerinin finansal performanslarının ölçülmesi ve sonuçlarının değerlendirilmesi büyük önem arz etmektesi bakımından literatüre katkı sağlayacă̆ı inancındayız.

Sayımızın yedinci makalesi olan ve Nurzahit KESKİN'in kaleme aldığı "Bir yönetim gurusu olarak Alfred D. Chandler ve işletme tarihi üzerindeki etkilerine yönelik analitik bir değerlendirme" başlıklı makalenin amacı modern işletme tarihinin babası kabul edilen Alfred D. Chandler, Jr.'ın işletme tarihi üzerindeki etkilerine yönelik analitik bir değerlendirme yapmaktır. Makalenin İşletme Bilimine gönül veren herkesin okuması gereken bir eser olduğunu düşünüyoruz.

Önceki sayılarımızda olduğu gibi bu sayımızda da gerçekleştirdiğimiz, işletmeciliğgin farklı disiplinlerinden değerli çalışmaları bir araya getirmek artık dergimizin geleneği haline gelmiştir. Sayımıza katkı sunan bilim insanlarına kıymetli çalışmalarıyla zengin bir içerik sunmamıza olana verdikleri için şükran duyuyoruz. Dergi politikası olarak bundan sonraki sayılarımızda da işletme bilimine dayalı farklı disiplinlerden gelen çalışmaları yayınlamaya özen göstereceğiz. Sayımızın hazırlanmasına katkı sunan hakemlerimize, editör kurulumuza, danışma kurulumuza ve dergi sekreteryamıza teşekkürlerimi sunarım. Dergimizin okurlarımı ve bilim insanlarına faydalı olması dileklerimle sonraki sayılarımızda işletmeciliğin güncel çalışmaların bilim dünyasının hizmetine sunmak için siz değerli bilim insanları ve araştırmacıların katkıların bekliyoruz.

Saygilarmizla...

Prof. Dr. Mahmut AKBOLAT Editör 


\title{
İÇINDEKİLER/CONTENTS
}

\author{
Yal (Year) 2020 Cilt (Vol.) 8 Sayı (No) 3
}

\section{Araștırma Makaleleri/Research Articles}

The strategic importance of e-complaints about the health services of the hospitals

Hastanelerde sağlık hizmetleri hakkındaki e-şikayetlerin stratejik önemi

Murat NAZLI ve Hande ARBAK

Uluslararası Mesleki Uygulama Çerçevesi Açısından İç Denetim Süreci Ve

Değerlendirilmesi

Internal Audit Process And Evaluation In Terms Of International Professional Practices

Framework

Ferda ALPER AY ve Canan UÇAR YENIHHAYAT

Programlanabilir güç cihazının ölçüm yeterliliğinin GAGE R\&R ile analiz edilmesi

Measuring qualification of the programmable power device By Gage RER analysis

Sibel SATICI, Recep SATICI ve Burcu ÖZCAN

Eskişehir destinasyon markasının geliştirilmesinde lületaşı

Meerschaum in the development of eskişehir destination brand

Ercan TAŞKIN, H. Yelda ŞENER ve Betül BILLGIÇ

Yönetici bir kadın ise lider prototipi farklılaşır mı?

Is the leader prototype different if the manager is a woman?

Güler SA ĞLAM ARI, Nuray GÜNERİ TOSUNOĞLU ve Berrin FİLIZÖZ

Havacılık işletmelerinde Rasyo yöntemi ile finansal performans ölçümü: Borsa İstanbul (BİST)'da işlem gören iki havayolu işletmesi üzerine bir araştırma

Measurement of financial performance by ratio method in aviation enterprises: a research on two

airlines enterprises trading in the Istanbul stock market

Dursun KELEŞ ve Abitter ÖZULUCAN

\section{Biografi/Biography}

Bir yönetim gurusu olarak Alfred D. Chandler ve işletme tarihi üzerindeki etkilerine yönelik analitik bir değerlendirme

Alfred D. Chandler as a management gurus and an analytical evaluation on his effects on business history

Işletme Bilimi Dergisi

Cilt:8 Sayı:3 


\title{
PROGRAMLANABİLİ GÜÇ CİHAZININ ÖLÇÜM YETERLILIIĞININ GAGE R\&R İLE ANALİZ EDİLMESİ
}

\author{
Arş. Gör. Sibel SATICI
}

Kocaeli Üniversitesi, Mühendislik Fakültesi, Endüstri Mühendisliği Bölümü sibel.ozkardes@kocaeli.edu.tr

ORCID ID: 0000-0002-2010-833X

\section{Recep SATICI}

Kocaeli Üniversitesi, Fen Bilimleri Enstitüsü, Endüstri Mühendisliği Anabilim Dalı recepsatici1992@gmail.com

ORCID ID: 0000-0002-0869-476X

\section{Dr. Öğr. Üyesi Burcu ÖZCAN}

\author{
Kocaeli Üniversitesi, Mühendislik Fakültesi, Endüstri Mühendisliği Bölümü \\ burcu.ozcan@kocaeli.edu.tr \\ ORCID ID: 0000-0003-0820-4238
}

\begin{abstract}
Öz
Amaç: Günümüzde kalite iyileştirme çalışmalarının asıl amacı değişkenliği azaltarak hatalı ürün üretimini en düşük seviyede gerçekleştirmektir. Kaliteyi arttırmak için yapılan çalışmalardan önce ölçüm sisteminin yeterliliğinin incelenmesi gerekmektedir. Çünkü üretim sürecinde uygun olmayan bir ürün üretildiğinde sürecin yeterliliği ile ilgili bir sorun olmamasına rağmen eğer ölçüm sistemi bunu ölçebilecek yeterliliğe sahip değilse ya da ölçüm hatalarından kaynaklanan değişkenlikler mevcut ise yapılacak kalite iyileştirme çalışmaları sonuçsuz kalabilmektedir. Bu durumu ortadan kaldırabilmek için öncelikle ölçüm sisteminin yeterliliğinin analiz edilmesi gerekmektedir. $\mathrm{Bu}$ çalışmada programlanabilir güç kaynağı cihazının ölçüm yeterliliğinin analiz edilmesi amaçlanmıştır.

Yöntem: Ölçüm sistemindeki değişkenlik tekrar edilebilirlik ve tekrar üretilebilirlik olmak üzere iki bileşene sahiptir. Tekrar edilebilirlik ölçüm cihazından kaynaklanan değişkenliği ifade ederken, tekrar üretilebilirlik ise operatör ve operatör-parça etkileşiminden kaynaklanan değişkenliği ifade etmektedir. Bu değişkenliklerin analizi Gage R\&R analizi olarak ifade edilmektedir. Bu analiz için genellikle Varyans Analizi (ANOVA) yöntemi kullanılmaktadır. Bu çalışmada güç kaynağı cihazının ölçüm yeterliliğinin Gage R\&R analizi için ANOVA yöntemi kullanılmıştır.
\end{abstract}

Bulgular: Bu çalışmada, beyaz eşya sektöründe faaliyet gösteren bir firmanın güvenlik laboratuvarındaki programlanabilir güç kaynağı cihazının EN 60335-1 
Programlanabilir

Güç Cihazının

Ölçüm

Yeterliliğinin

Gage R\&R İle Analiz Edilmesi

428

standardına göre çay makinesi güç ölçümü için yeterliliği Gage R\&R yöntemi ile analiz edilmiştir. Çalışmada, 3 operatör farklı zaman dilimlerinde 10 adet çay makinesinin 2'şer kez gücünü ölçmüştür.

Sonuç: Analizden elde edilen sonuçlar toplam değişkenliğin \%1,34'ünün ölçüm sisteminin değişkenliğinden, \%98,66'sını ise parça değişkenliğinden kaynaklandığını göstermektedir. Ölçüm sisteminin değişkenliğinin \%1,24'ü operatörden, \%0,10'u ise ölçüm cihazından kaynaklanmaktadır. Ölçüm sisteminin kabul edilebilirliğini değerlendirmek için yaygın olarak kullanılan göstergelerden birisi olan \%R\&R, ölçüm sisteminin hassasiyetinin toplam toleransa oranını yüzdesel olarak ifade eden $\% \mathrm{P} / \mathrm{T}$ ve ölçüm sisteminin kalitesine ilişkin göstergelerden birisi olan ve farklı kategori sayısı olarak da ifade edilebilen Sinyalgürültü oranı (SNR) değerleri ele alınmıştır. Analiz sonucunda \%R\&R değeri 11,56; $\% \mathrm{P} / \mathrm{T}$ değeri 9,87; SNR değeri ise 12 olarak elde edilmiştir. Bu değerler literatürde belirtilen istenilen değerlere sahip olduğundan ölçüm sisteminin çay makinesinin gücünü ölçmek için yeterli olduğunu söylemek mümkündür.

Anahtar kelimeler: Programlanabilir Güç Cihazı, Gage R\&R Analizi, Ölçüm Sistemi

\title{
MEASURING QUALIFICATION OF THE PROGRAMMABLE POWER DEVICE BY GAGE R\&R ANALYSIS
}

\begin{abstract}
Aim: Today, the main purpose of quality improvement studies is to reduce the variability and realize the production of faulty products at the lowest level. Sufficiency of the measurement system should be examined before the studies to increase the quality are conducted. Because when an inappropriate product is produced in the production process, although there is no problem with the adequacy of the process, if the measurement system is not capable of measuring it or there are variations due to measurement errors, the quality improvement studies to be performed may be inconclusive. In order not to waste the efforts made to increase the quality, it is necessary to analyze the adequacy of the measurement system first. This study aims to analyze the measurement capability of the programmable power supply device.

Method: The variability in the measuring system has two components: repeatability and reproducibility. Repeatability refers to variability arising from the measuring instrument, while reproducibility refers to variability arising from operator and operator-part interaction. The analysis of these variations is expressed as Gage R\&R analysis. Analysis of variance (ANOVA) method is generally used for this analysis. In this study, ANOVA method was used for Gage R\&R analysis of the measurement capability of the power supply device.
\end{abstract}


Findings: In this study, the adequacy of the programmable power supply device in the security laboratory of a company operating in the white goods sector for tea machine power measurement according to EN 60335-1 standard was analyzed by Gage R\&R method. In the study, 3 operators measured the power of 10 tea machines 2 times at different times.

Result: The results obtained from the analysis show that $1.34 \%$ of the total variability is caused by the variability of the measurement system and $98.66 \%$ is due to the part variability. $1.24 \%$ of the variability of the measurement system is caused by the operator and $0.10 \%$ is due to the measuring device. To evaluate the acceptability of the measurement system, \%R\&R, which is one of the indicators commonly used, $\% \mathrm{P} / \mathrm{T}$, which expresses the ratio of the sensitivity of the measurement system to the total tolerance as a percentage, and the Signal-to-noise ratio (SNR, which can also be expressed as the number of different categories) values, which is one of the indicators of the quality of the measurement system, were discussed. According to the results obtained from the analysis, the \%R\&R value is 11.56 ; $\% \mathrm{P} / \mathrm{T}$ value 9.87 ; SNR value was obtained as 12 . Since these values have the desired values stated in the literature, it is possible to say that the measuring system is sufficient to measure the power of the tea machine.

Keywords: Programmable Power Device, Gage R\&R Analysis, Measurement System

\section{GİRIŞ}

Kalite iyileştirme çalışmalarının amaçları arasında değişkenliği azaltma ve hatalı ürün üretimini sıfıra indirme bulunmaktadır. Bir ürünün uygun olmadığı tespit edildiğinde genellikle değişkenlik prosesle ilişkilendirilir ve bu nedenle proses kapasitesini artırmak için iyileştirmeler yapılmaktadır. İzlenilen sürecin doğru olmasına rağmen ölçüm sisteminin yetersizliği sebebiyle iyileştirme için harcanan çabalar sonuçsuz kalabilmektedir. Ölçüm sisteminin yeterli olduğu durumlarda ise ölçüm yaparken yapılan hatalar proses değişkenliği ile karşılaştırıldığında kabul edilemez seviyede olabilmektedir. Bu nedenle iyileştirme çalışmalarından önce bir ölçüm sisteminin ya da üretim sürecinin değişkenliğinin incelenmesi gerekmektedir. Bu durum ölçüm sisteminin yeterli olup olmadığının nasıl belirlenmesi gerektiği problemini ortaya çıkarmıştır.

Üretim ortamında, laboratuvar ortamında ya da herhangi bir araştırmada eğer bir ölçüm sistemi kullanılacaksa bunun öncelikle doğrulanması gerekmektedir. Çünkü ölçümlerin toleranslar içerisinde yer alıp almadığının belirlenmesi ancak yeterli bir ölçüm sisteminin varlığı ile mümkün olmaktadır. Bu nedenle bir ölçüm sisteminin yeterliliğinin belirlenmesi kalite iyileştirme çabaları için önemli bir unsurdur. Bir ölçüm
Programlanabilir Güç Cihazının Ölçüm Yeterliliğinin Gage R\&R İle Analiz Edilmesi 429 
Programlanabilir

Güç Cihazının

Ölçüm

Yeterliliğinin

Gage R\&R İle Analiz Edilmesi

430 sistemi ile bir parçanın boyutlarının ölçüldüğünü varsaydığımızda, ölçüm sistemi bize her zaman parçanın kesin boyutuna ilişkin sonuçları vermemektedir. Ölçüm sisteminin yetersizliğinden dolayı yapılan yanlış ölçümler ürünün kalite açısından doğru değerlendirilememesine neden olabilmektedir. Ölçülen değerler bazı hatalardan dolayı gerçek değerden sapan ölçümlerdir. Bu ölçüm işlemi sırasında meydana gelen değişkenliğin bir kısmı ölçülen parçadan bir kısmı operatörden bir kısmı da ölçüm sisteminden kaynaklanabilmektedir. Genellikle ölçüm sistemini iyileştirme çalışmalarının üç amacı bulunmaktadır. Bunlar, ölçülen toplam değişkenliğin ne kadarının ölçüm sistemine bağlı olduğunu belirlemek; sistemdeki değişkenlik kaynaklarını izole etmek ve daha kapsamlı bir projede ya da uygulamada sistemin kullanılıp kullanılamayacağ konusunda karar vermektir (Burdick, 2003). Birçok ölçüm sistemi yeterlilik çalışmasında, ölçüm sistemi parça üzerinde farklı operatörler tarafından farklı zaman dilimlerinde tekrar ölçümler elde etmek için kullanılmaktadır. $\mathrm{Bu}$ tür çalışmalarda ölçüm sisteminin değişkenliği iki bileşenden oluşmaktadır. Bunlar, tekrar edilebilirlik (repeatability) ve tekrar üretilebilirliktir (reproducibility) (AIAG, 2002). Tekrar edilebilirlik, sistemde aynı parça için aynı operatör ve aynı zaman dilimlerinde ölçüm yapıldığında sistemden ya da ölçüm cihazından kaynaklanan değişkenliği ifade etmektedir. Tekrar üretilebilirlik ise operatörlerden ya da zamandan kaynaklanan değişkenliği ifade etmektedir. Bu yapılan çalışmalarda sistemin tekrar edilebilirliği ve tekrar üretilebilirliği Gage $R \& R$ şeklinde ifade edilmektedir.

Gage R\&R çalışmaları, çeşitli endüstriyel uygulamalardaki ölçüm sistemlerini değerlendirmek için yaygın olarak yürütülmüştür. Gage R\&R çalışmalarında sistemi analiz etmek ve değişkenlik bileşenlerini tahmin etmek için iki yönlü ANOVA kullanımı oldukça yaygındır (Al-Refaie \& Bata, 2010). Vardeman ve Vanvalkenburg (1999) tarafından yapılan çalışmada iki yönlü rastgele etki modellerinin Gage $R \& R$ çalışmaları için kullanımı mevcut uygulamalara eleştirel bir gözle bakmak ve bazı basit gelişmelere işaret etmek amacıyla basit terimlerle açıklanmıştır.

Bu çalışmada, beyaz eşya sektöründe faaliyet gösteren bir firmanın güvenlik laboratuvarındaki programlanabilir güç kaynağı cihazının TS EN 60335-1 standardına göre çay makinesi güç ölçümü için yeterliliği Gage R\&R yöntemi ile analiz edilmiştir. Çalışmada, firma tarafından üretimi yapılan 10 adet çay makinesi için 3 operatör tarafından farklı zaman dilimlerinde 2'şer kez güç ölçümü yapılmıştır. Ölçüm sisteminin yeterliliğinin belirlenmesi problemini çözmek için farklı yöntemlerin kullanıldığı analizler yapılmaktadır. Bu çalışmada ise Gage $R \& R$ analizi için ANOVA yöntemi 
kullanılmıştır. Ölçüm sisteminin kabul edilebilirliğini değerlendirmek için yaygın olarak kullanılan göstergelerden birisi olan \%R\&R, ölçüm sisteminin hassasiyetinin toplam toleransa oranını yüzdesel olarak ifade eden $\% \mathrm{P} / \mathrm{T}$ ve ölçüm sisteminin kalitesine ilişkin göstergelerden birisi olan Sinyal-gürültü oranı (SNR) değerleri ele alınmıştır. Analizden elde edilen sonuçlar toplam değişkenliğin \%1,34'ünün ölçüm sisteminin değişkenliğinden \%98,66'sının ise parça değişkenliğinden kaynaklandığını göstermektedir. Ölçüm sisteminin değişkenliğinin \%1,24'ü tekrar üretilebilirlikten \%0,10'u ise tekrar edilebilirlikten kaynaklanmaktadır. Yapılan analizden elde edilen sonuçlara göre \%R\&R değeri 11,56; \%P/T değeri 9,87; SNR değeri ise 12 olarak elde edilmiştir. $\mathrm{Bu}$ değerler literatürde belirtilen istenilen değerlere sahip olduğundan ölçüm sisteminin çay makinesinin gücünü ölçmek için yeterli olduğunu söylemek mümkündür.

\subsection{Literatür İncelemesi}

Literatürde Gage $R \& R$ analizi ile ilgili yapılan çalışmalar incelenmiştir. Otomotiv sektörü, sağlık sektörü, ilaç sektörü, enerji sektörü gibi farklı alanlarda bu konuyla ilgili yapılmış çalışmalar mevcuttur.

Burdick ve ark. (2003) çalışmalarında varyans analizini göz önünde bulundurarak ölçüm sistemlerinin yeterliliklerinin incelenmesi üzerine istatistiksel yöntemler üzerinde durmuştur. ANOVA yöntemindeki ilgili parametrelere ilişkin güven aralığı oluşturulması vurgulanmıştır. Güven aralığ1 oluşturulmasına ilişkin kullanılan uyarlanmış geniş örneklem yöntemine ilişkin ele alan bir yaklaşıma Burdick ve Larsen (1997) tarafından yapılan çalışmada yer verilmiştir.

Gao et al. (2007) yaptıkları çalışmada ilaç sektöründeki dissolüsyon test ölçüm sistemlerinin aparat, operatör ve tablet kaynaklı değişkenliğini incelemek üzere Gage R\&R kullanmıştır.

Erdman et al. (2010) sağlık sektöründe yaptıkları çalışmada hemşirelerin kulak termometresi ile yaptıkları vücut sıcaklığı ölçümlerini Gage R\&R analizinin ilkeleri doğrultusunda değerlendirmiştir. Çalışmanın sonucunda Gage R\&R çalışması, mevcut ölçüm prosedürü ile bir ölçümün gerçek sicaklıktan 0,64 dereceye kadar değişebileceğini göstermiştir. Bu da yapılan ölçümlerin güvenilirliğinin \%99 olduğunu göstermektedir.

Peruchi ve ark. (2013) çalışmalarında korelasyon özelliklerine sahip ölçüm sistemlerinin Gage R\&R yöntemi ile nasıl analiz edildiği araştırmıştır. Bu çalışmanın literatüre katkısı ölçüm sisteminin çok değişkenli analizi için ağırlıklı ana bileşenlerin göz önünde bulundurulduğu bir yöntem önermesidir.
Programlanabilir

Güç Cihazının Ölçüm Yeterliliğinin

Gage R\&R İle Analiz Edilmesi 
Programlanabilir

Güç Cihazının

Ölçüm

Yeterliliğinin

Gage R\&R İle

Analiz Edilmesi

432
Aquila ve ark. (2018) iç içe Gage R\&R yöntemini kullanarak Brezilya'da rüzgar enerjisi üreten dört ana eyalette ortalama rüzgar hızı davranışlarını değerlendirmeyi amaçlamıştır. Bu dört eyalette 2012-2015 yılları arasında her aya ilişkin rüzgarın ortalama hızları toplanmıştır. Bu çalışmada mevsimsellik etkisi, yıllar boyunca tekrarlanan ölçümler ve eyaletler arasındaki rüzgar ortalama hızı arasındaki fark değerlendirilmiştir. Elde edilen sonuçlar bu üç faktörün etkisinin istatistiksel olarak anlamlı olduğunu göstermiştir.

Wrzochal ve Adamczak (2019) tarafından yapılan çalışmada rulmanların titreşimlerini ölçen ölçüm sisteminden elde edilen sonuçlarla en iyi tekrar edilebilirlik ve tekrar üretilebilirlik parametrelerini belirlemek için Gage R\&R kullanılmıştır.

Literatürdeki bazı çalışmalarda ölçüm sistemlerini değerlendirmek için farklı yöntemler kullanılmıştır. Lin et al. (1997) ölçüm değişkenliğini azaltmak için Taguchi yöntemini kullanmıştır. Ayrıca bu çalışmada Gage $R \& R$ çalışması yapılarak iyileştirmeler doğrulanmış, ürün değişkenliği üzerindeki azaltma etkisini göstermek için süreç yeterlilik analizi kullanılmıştır.

Majeske (2008) tarafından yapılan çalışmada otomotiv gövde paneli için ölçüm sisteminden elde edilen veriler kullanılmıştır. Genellikle ölçüm sisteminin analizinde kullanılan her bir gösterge tek bir değişkeni ifade ettiği kabul edilirken bu durum otomotiv gövde paneli üretimi için ise ölçüm sisteminin kalitesine ilişkin birçok gösterge ele alınmaktadır. Bu nedenle ölçüm sisteminin kalitesini incelemek için dört farklı gösterge kullanılmıştır. Bu çalışmada bir faktörlü, iki faktörlü ve üç faktörlü ölçüm sistemleri için varyans-kovaryans matrisini tahmin etmede Çoklu Varyans Analizi yöntemi (MANOVA) kullanılmıştır.

\section{YÖNTEM}

Kararlı koşullar altında bulunan bir ölçüm sisteminden çoklu bir şekilde elde edilen ölçümlerin istatistiksel özellikleri ile ölçüm verilerinin kalitesi ifade edilmektedir. Gage R\&R'ın amacı esas süreç değişkenliğini ortaya çıkarmak için ölçüm sisteminden kaynaklanan değişkenliği saptayarak sistem değişkenliğinden ayrıştırmaktır. Bu ayrıştırmanın temel nedeni toplam değişkenliğin hem süreç değişkenliğinden hem de ölçüm sisteminden kaynaklanıyor olmasıdır. Amaç, ihtiyaçlar doğrultusunda bir ölçüm sistemi geliştirmektir. İhtiyaçlara uygun bir ölçüm sisteminin doğru ve hassas bir şekilde ölçüm yapması gerekmektedir. Ölçüm sisteminin doğru ölçüm yapması, ölçüm sisteminin sapmaya veya sistematik ölçüm hatasına maruz kalma derecesi olarak tanımlanırken, ölçüm sisteminin 
hassas olması ise ölçüm sisteminin aynı nesne üzerinde tekrarlanan ölçümlerin standart sapması olan ölçüm yayılımına maruz kalma derecesi olarak tanımlanabilir.

Ölçüm sistemi sonucunda ölçümü yapılan ürünün toplam değişkenliği süreçten ya da parçadan kaynaklanan değişkenlik ve ölçüm sisteminden kaynaklanan değişkenlik olmak üzere iki faklı bileşenden oluşmaktadır. Bunlar Denklem 1'de ifade edilmektedir. Ölçüm sistemi "Gage" olarak adlandırılmaktadır.

$$
\sigma_{\text {Toplam }}^{2}=\sigma_{\text {Parça }}^{2}+\sigma_{\text {Gage }}^{2}
$$

Süreçten kaynaklanan değişkenlik, ölçümü yapılan parçanın üretimi sırasında oluşan değişkenliği temsil etmektedir. Ölçüm sisteminden kaynaklanan değişkenlik ise ölçüm sisteminin belirsizliğinden kaynaklanan değişkenliği temsil etmektedir. Toplam değişkenliğin karesi, parçadan kaynaklı değişkenliğinin karesi ve ölçüm sisteminden kaynaklı değişkenliğin karesinin toplamına eşittir. Ölçüm sisteminden kaynaklanan değişkenlik tekrar edilebilirlik ve tekrar üretilebilirlik olmak üzere iki farklı bileşenden oluşmaktadır. Bunlar Denklem 2' de ifade edilmektedir.

$$
\sigma_{\text {Gage }}^{2}=\sigma_{\text {Tekrar edilebilirlik }}^{2}+\sigma_{\text {Tekrar } \text { üretilebilirlik }}^{2}
$$

Tekrar edilebilirlik, ölçüm cihazından kaynaklanan değişkenlik olarak ifade edilmektedir. Diğer bir deyişle, aynı operatörün, aynı parçayı, aynı ölçüm cihazı ile ölçtügünde ortaya çıkan değişkenliktir. Tekrar üretilebilirlik ise operatörden kaynaklanan değişkenlik olarak ifade edilmektedir. Diğer bir deyişle, aynı parçanın, aynı ölçüm cihazı ile farklı operatörler tarafından ölçüm yapılmasıyla ortaya çıkan değişkenliktir. Tekrar üretilebilirlik hem operatörlerin farklılıklarından kaynaklanan etkiyi hem de operatör-parça etkileşiminden kaynaklanan etkiyi içermektedir. Toplam değişkenliği etkileyen faktörler Şekil 1'de gösterilmektedir.

\subsection{Yöntem Çeşitleri}

Gage R\&R yöntemlerinden birisi olan Average \& Range (A\&R) yöntemi tekrar sayısı iki veya üç olduğunda kullanılmaktadır. Bu yöntem, ölçüm sistemlerinin tekrarlanabilirliğini ve tekrar üretilebilirliliğini tahmin etmek için kullanılmaktadır. Ölçüm sisteminin değişkenliğini belirleyebilmek için $\bar{X}$ grafiği ve R grafiği kullanılmaktadır.

Bu çalışmada da kullanılan diğer bir Gage R\&R yöntemi ise Varyans Analizi (ANOVA) yöntemidir. Bu yöntem ölçüm sistemlerinin tekrarlanabilirliğini ve tekrar üretilebilirliliğini tahmin etmek için kullanılmaktadır. Bu yöntemin amacı, ölçüm sisteminin maksimum
Programlanabilir Güç Cihazının Ölçüm Yeterliliğinin Gage R\&R İle Analiz Edilmesi 433 
İşletme Bilimi Dergisi (JOBS), 2020; 8(3): 427-447. DOI: 10.22139/jobs.762798

Programlanabilir

Güç Cihazının

Ölçüm

Yeterliliğinin

Gage R\&R İle

Analiz Edilmesi

434

değişkenliğini ölçüm yapılan parçadan kaynaklanan değişiklik ve ölçüm sisteminden kaynaklanan değişiklik olarak ayırmaktır.

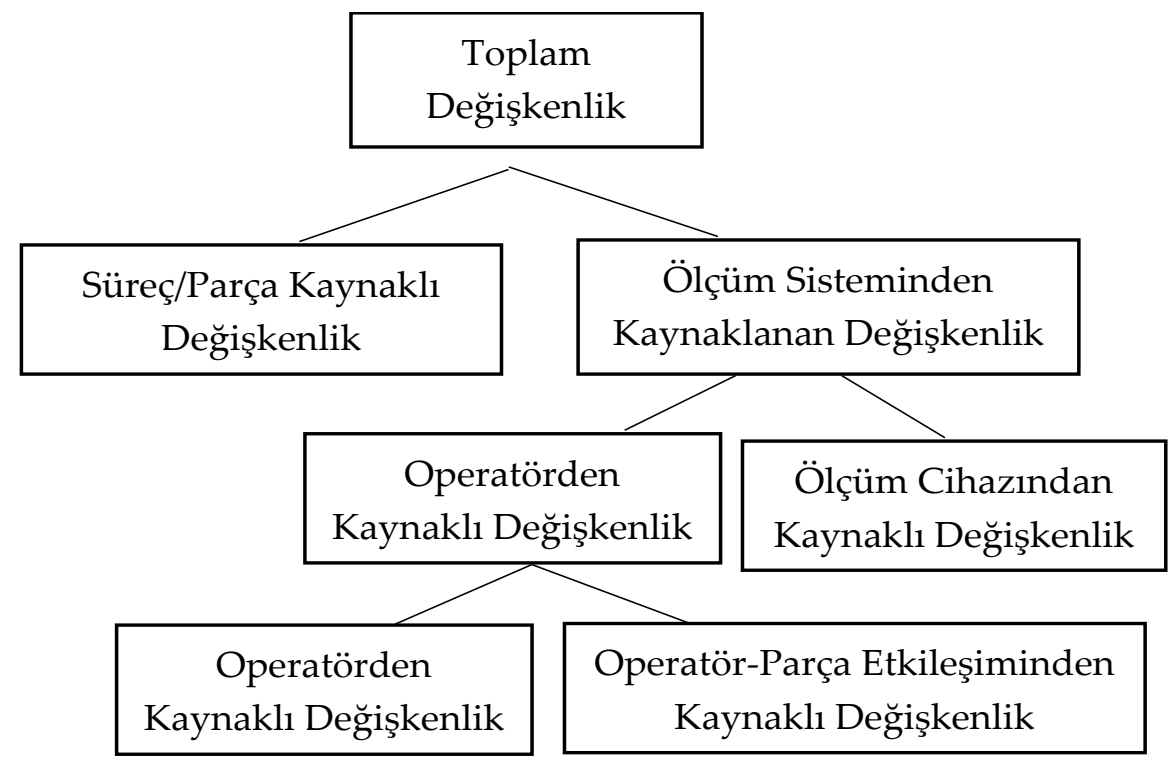

Şekil 1.

Toplam Değişkenliği Etkileyen Faktörler

Bir ölçüm cihazının veya tezgâhının başlangıç aşamasında; yeni bir operatörü değerlendirmede; cihaz kalibrasyonundan sonra ya da ölçüm sisteminin toleranslar açısından yeterince hassas olmadığından şüphe edildiğinde bu yöntem kullanılmaktadır. ANOVA yönteminin A\&R yönteminden farkı ölçüm sistemini değerlendirirken parça-operatör etkileşimini de dikkate almasıdır. Bu yöntemde tekrar üretilebilirlikten kaynaklanan değişkenlik, operatörden kaynaklı değişkenlikten ve operatörparça etkileşiminden kaynaklı değişkenlikten oluşmaktadır. Denklem 2, ve Denklem 3 bir arada düşünüldüğünde Denklem 4 ortaya çıkmaktadır. Denklem 1 ve Denklem 4 birlikte düşünüldügünde Denklem 5 ortaya çıkmaktadır.

$$
\begin{gathered}
\sigma_{\text {Tekrar üretilebilirlik }}^{2}=\sigma_{\text {Operatör }}^{2}+\sigma_{\text {Operatör x Parça }}^{2} \\
\sigma_{\text {Gage }}^{2}=\sigma_{\text {Operatör }}^{2}+\sigma_{\text {Operatör x Parça }}^{2}+\sigma_{\text {Tekrar edilebilirlik }}^{2} \\
\sigma_{\text {Toplam }}^{2}=\sigma_{\text {Parç̧a }}^{2}+\sigma_{\text {Operatör }}^{2}+\sigma_{\text {Operatör x Parça }}^{2}+\sigma_{\text {Tekrar edilebilirlik }}^{2}
\end{gathered}
$$

\subsection{Yöntemin Adımları}

Bu çalışmada, Gage R\&R analizinde ANOVA yöntemi kullanılmıştır. Kullanılan yöntemi üç adımda özetlemek mümkündür (Al-Refaie \& Bata, 2010): 
İlk olarak Gage R\&R ölçüm modelinin geliştirilmesi adımı yer almaktadır. Rastgele seçilmiş $p$ tane parça olduğu varsayılmaktadır. Rastgele seçilmiş operatörün her biri $n$ kez aynı ölçüm cihazı ile parçayı ölçmektedir. Bu durumda $y_{i j k} j$ operatörü tarafından ölçülen $i$ parçasının $k$ tekrarlı ölçümünü ifade etmektedir ve Denklem 6' daki gibi gösterilmektedir.

$$
y_{i j k}=x+P_{i}+O_{j}+(P O)_{i j}+\varepsilon_{i j k}\left\{\begin{array}{l}
i=1,2, \ldots p \\
j=1,2, \ldots, o \\
k=1,2, \ldots, n
\end{array}\right.
$$

Denklem $6^{\prime}$ da gösterilen $x$, ölçümün gerçek değerini ifade etmektedir. $P_{i}, O_{j}$ ve $(P O)_{i j}$ parça, operatör ve parça-operatör etkileri için ifade edilen bağımsız parametrelerdir. $\varepsilon_{i j k}$ ise hata terimidir. $\mathrm{Bu}$ parametreler ortalaması 0 ve varyansları sirasılyla $\sigma_{\text {Parçar }}^{2} \sigma_{\text {Operatör }}^{2}$ $\sigma_{\text {Operatör } x \text { Parça }}^{2} \sigma_{\text {Tekrar edilebilirlik }}^{2}$ olan normal dağılıma sahiptir. Böylelikle herhangi bir ölçümün toplam varyansı Denklem 5'teki gibi gösterilmektedir.

İkinci adım olarak Gage R\&R analizi için ANOVA modelinin geliştirilmesi yer almaktadır. İki yönlü ANOVA Gage R\&R analizindeki bileşenlerin varyanslarını tahmin etmek için kullanılmaktadır. Denklem 5 'teki ifadeye dayanarak kareler toplam Denklem 7'deki şekilde gösterilmektedir.

$$
S S_{\text {Toplam }}=S S_{\text {Parça }}+S S_{\text {Operatör }}+S S_{\text {Operatör x Parça }}+S S_{\text {Tekrar edilebilirlik }}
$$

Denklem $\quad 7$ 'deki $\quad S S_{\text {Parça }} \quad S S_{\text {Operatör, }} \quad S S_{\text {Operatör x Parça' }}$ $S S_{\text {Tekrar edilebilirlik }}$ ifadeleri sırasıyla parçanın, operatörün, operatör ve parça etkileşiminin ve tekrar edilebilirliğin kareleri toplamını göstermektedir. Denklem 5'te gösterilen bileşenlerin varyansları Denklem 8, Denklem 9, Denklem 10 ve Denklem 11'de gösterilen eşitlikler ile tahmin edilmektedir.

$$
\begin{gathered}
\hat{\sigma}_{\text {Parça }}^{2}=\frac{M S_{\text {Parça }}-M S_{\text {Operatör x Parça }}}{\text { on }} \\
\hat{\sigma}_{\text {Operatör }}^{2}=\frac{M S_{\text {Operatör }}-M S_{\text {Operatör } x \text { Parça }}}{p n} \\
\hat{\sigma}_{\text {Operatör x Parça }}^{2}=\frac{M S_{\text {Operatör } x \text { Parça }-M S_{\text {Tekrar edilebilirlik }}}}{n} \\
\hat{\sigma}_{\text {Tekrar edilebilirlik }}^{2}=M S_{\text {Tekrar edilebilirlik }}
\end{gathered}
$$

Son adımda ölçüm sisteminin yeterliliğini değerlendirmek amacıyla literatürde bu konuyla ilgili yapılan çalışmalarda da yer alan bazı göstergelerin kullanılması yer almaktadır. Literatürde yer alan çalışmalar incelendiğinde ölçüm sisteminin kabul edilebilirliğinin ölçülmesi için yaygın olarak kullanılan göstergelerden birisinin \%R\&R olduğu görülmüştür. Bu gösterge ölçüm sisteminden kaynaklı değişkenliğin toplam değişkenliğe oranını ifade etmektedir. Denklem 12' de nasıl hesapladığı gösterilmektedir. 
İşletme Bilimi Dergisi (JOBS), 2020; 8(3): 427-447. DOI: 10.22139/jobs.762798

Programlanabilir

Güç Cihazının

Ölçüm

Yeterliliğinin

Gage R\&R İle

Analiz Edilmesi

436

$$
\% R \& R=\frac{\sigma_{\text {Ölçüm Sistemi }}}{\sigma_{\text {Toplam }}} \times 100
$$

\%R\&R değerinin değerlendirilmesine ilişkin bilgilere Tablo 1'de yer verilmektedir (AIAG, 2010; Al-Refaie \& Bata, 2010).

Tablo 1.

$\% R \& R$ Değerleri

\begin{tabular}{ll} 
\%R\&R Değerleri & Durum \\
\hline$\% R \& R \leq 10$ & İstenilen değer \\
$10<\% R \& R \leq 30$ & Kabul edilebilir \\
$\% R \& R>30$ & Kabul edilemez \\
\hline
\end{tabular}

Gage R\&R analizinde kullanılan göstergelerden bir diğeri de $\mathrm{P} / \mathrm{T}$ oranıdır (AIAG, 2002). Bu oran ölçüm sisteminin hassasiyetinin toplam toleransa oranı şeklinde ifade edilmektedir. Yüzde olarak Denklem 13'teki gibi gösterilmektedir.

$$
\% P / T=\frac{6 \times \sigma_{\ddot{o ̈ l c ̧ u ̈ m ~ S i s t e m i ~}}}{\text { Tolerans }}
$$

\%P/T değerinin \%10 veya daha az olması durumunda ölçüm sisteminin yeterli olduğunu söylemek mümkündür. Bu değerin \%30' dan büyük olması ise ölçüm sisteminin yetersiz olduğunu göstermektedir (AIAG, 2002).

Ölçüm sistemi ile ilgili kalite göstergelerinden bir diğeri de sinyalgürültü oranıdır (Al-Refaie \& Bata, 2010). Bu oran farklı kategori sayısı olarak da ifade edilmektedir (Peruchi et al., 2013). SNR ya da S/N şeklinde gösterilmektedir. Burada sinyal parçanın değişkenliğini, gürültü ise ölçüm sisteminin değişkenliğini ifade etmektedir. SNR değeri Denklem 14'teki gibi hesaplanmaktadır. Bu değer ölçüm sisteminin parçaları kaç gruba ayırabildiğini göstermektedir.

$$
S N R=\frac{\sqrt{2} \sigma_{P a r c ̧ a} a}{\sigma_{\text {ölçüm Sistemi }}}
$$

SNR değerinin 5 veya daha büyük olması ölçüm sisteminin yeterli olduğunu göstermektedir. Bu değer 2'den küçük olduğunda ölçüm sisteminin yetersiz olduğunu söylemek mümkündür (Burdick et al., 2003).

\section{UYGULAMA ÇALIŞMASI}

Ev ve benzeri yerlerde kullanılan elektrikli cihazlar için güvenlik kuralları TS EN 60335-1 standardında belirtilmektedir. Bu çalışmada bu standarda göre test yapan uluslararası bir güvenlik laboratuvarında bulunan programlanabilir güç cihazı ile elektrikli çay makinesinin güç ölçümü yapılarak bir Gage R\&R çalışması yapılmıştır. Firmanın güvenlik laboratuvarında üretilen ürünlerin standartlara uygun olup olmadığını test 
eden ölçüm sisteminin yeterliliğinin değerlendirmesi adına yapılan analizler bu çalışma ile başlamıştır. Bu çalışmanın amacı ölçüm sistemindeki ve programlanabilir güç cihazındaki değişkenlikleri belirleyerek, ölçüm sisteminin güç ölçümünü yapmak ve çay makinelerinin güçlerinin istenilen standartlarda olduklarını belirleyebilmek için yeterli olup olmadığını belirlemektir.

Gage R\&R çalışmalarında sık görülen ve kabul edilebilir bir yaklaşımla örneklem sayısı belirlenebilmektedir. Bu yaklaşımda parça sayısı, operatör sayısı ve tekrar sayısının çarpımı ile elde edilecek veri noktası sayısının 60 olması gerektiğine yer verilmiştir. Ayrıca operatör sayısının 4, tekrar sayısının 3 olması ile elde edilen sonuçların ölçüm sistemine ilişkin bir gelişme yaratmadığ 1 ortaya çıkmıştır (Minitab, 2017). Bu nedenle bu çalışmada 3 operatör, 10 adet parçayı 2'şer kez ölçmüştür. Toplamda 60 veri noktasından oluşan bir örneklem kullanılmıştır. Operatörlerin ölçüm sıralarını belirlemek için Minitab programının Gage R\&R modülü kullanılmıştır. Böylelikle ölçüm sırası yani hangi operatörün hangi çay makinesini test edeceği rassal olarak belirlenmiştir. Çay makinelerinin ölçüm sırasının rassal olarak belirlenmesi operatörlerin numunelerden daha az etkilenmesine sebep olmaktadır. Ayrica operatörlerin iki ölçümü arasındaki etkileşimini de en aza indirmek için ölçümler farklı haftalarda yapılmıştır. Belirlenen ölçüm sırasına göre ölçümler yapıldıktan sonra değerler tablo haline getirilmiştir. Tablo 2'de ölçüm sonuçları gösterilmektedir. Ölçümü yapılan çay makinesinin beyan gücü $230 \mathrm{~V}$ için $1600 \mathrm{~W}$ idi. TS EN 60335-1 standardına göre 1sitmalı cihazlar için güç tolerans değerleri $+\% 5$ ve $-\% 10$ 'dur. Bu değerlere göre güç ölçümü yapılan çay makinesinin tolerans değerleri alt sınır için $1440 \mathrm{~W}$, üst sınır için ise $1680 \mathrm{~W}$ olmaktadır. Ölçüm tablosu oluşturulduktan sonra Minitab programının "Gage R\&R Study Crossed" modülü ile analiz yapılmıştır.
Programlanabilir

Güç Cihazının Ölçüm Yeterliliğinin Gage R\&R İle Analiz Edilmesi 
İşletme Bilimi Dergisi (JOBS), 2020; 8(3): 427-447. DOI: 10.22139/jobs.762798

Programlanabilir

Güç Cihazının

Ölçüm

Yeterliliğinin

Gage R\&R İle Analiz Edilmesi
Tablo 2.

Ölçüm Sonuçları

\begin{tabular}{|c|c|c|c|c|c|c|c|}
\hline $\begin{array}{l}\text { Ölçüm } \\
\text { Sırası }\end{array}$ & Parça & Operatör & $\begin{array}{c}\text { Ölçüm } \\
\text { Değeri } \\
\text { (W) }\end{array}$ & $\begin{array}{l}\text { Ölçüm } \\
\text { Sırası }\end{array}$ & Parça & Operatör & $\begin{array}{l}\text { Ölçüm } \\
\text { Değeri } \\
\text { (W) }\end{array}$ \\
\hline 1 & 7 & Operatör-1 & 1543,7 & 31 & 6 & Operatör-1 & 1561,9 \\
\hline 2 & 10 & Operatör-1 & 1604,6 & 32 & 10 & Operatör-1 & 1602,9 \\
\hline 3 & 2 & Operatör-1 & 1575,7 & 33 & 9 & Operatör-1 & 1638,1 \\
\hline 4 & 4 & Operatör-1 & 1552,2 & 34 & 7 & Operatör-1 & 1543,4 \\
\hline 5 & 6 & Operatör-1 & 1563,4 & 35 & 4 & Operatör-1 & 1551,9 \\
\hline 6 & 5 & Operatör-1 & 1525,4 & 36 & 3 & Operatör-1 & 1600,2 \\
\hline 7 & 8 & Operatör-1 & 1562,5 & 37 & 1 & Operatör-1 & 1548,6 \\
\hline 8 & 1 & Operatör-1 & 1548,2 & 38 & 5 & Operatör-1 & 1524,6 \\
\hline 9 & 9 & Operatör-1 & 1638,1 & 39 & 8 & Operatör-1 & 1561,7 \\
\hline 10 & 3 & Operatör-1 & 1599,7 & 40 & 2 & Operatör-1 & 1575,4 \\
\hline 11 & 6 & Operatör-2 & 1571,7 & 41 & 2 & Operatör-2 & 1582,2 \\
\hline 12 & 7 & Operatör-2 & 1548,5 & 42 & 4 & Operatör-2 & 1560,1 \\
\hline 13 & 10 & Operatör-2 & 1609,2 & 43 & 7 & Operatör-2 & 1548,5 \\
\hline 14 & 2 & Operatör-2 & 1582,5 & 44 & 1 & Operatör-2 & 1553,9 \\
\hline 15 & 9 & Operatör-2 & 1644,9 & 45 & 8 & Operatör-2 & 1568,4 \\
\hline 16 & 8 & Operatör-2 & 1568,4 & 46 & 3 & Operatör-2 & 1608,6 \\
\hline 17 & 1 & Operatör-2 & 1557,8 & 47 & 10 & Operatör-2 & 1608,2 \\
\hline 18 & 5 & Operatör-2 & 1532,1 & 48 & 6 & Operatör-2 & 1570,1 \\
\hline 19 & 3 & Operatör-2 & 1608,8 & 49 & 9 & Operatör-2 & 1644,7 \\
\hline 20 & 4 & Operatör-2 & 1558,5 & 50 & 5 & Operatör-2 & 1531,5 \\
\hline 21 & 7 & Operatör-3 & 1544 & 51 & 9 & Operatör-3 & 1639 \\
\hline 22 & 10 & Operatör-3 & 1605,9 & 52 & 4 & Operatör-3 & 1552,1 \\
\hline 23 & 3 & Operatör-3 & 1599,7 & 53 & 8 & Operatör-3 & 1561,9 \\
\hline 24 & 5 & Operatör-3 & 1524,3 & 54 & 6 & Operatör-3 & 1562,1 \\
\hline 25 & 6 & Operatör-3 & 1566,6 & 55 & 10 & Operatör-3 & 1603,7 \\
\hline 26 & 8 & Operatör-3 & 1564,1 & 56 & 1 & Operatör-3 & 1548,8 \\
\hline 27 & 4 & Operatör-3 & 1551,9 & 57 & 7 & Operatör-3 & 1544,1 \\
\hline 28 & 2 & Operatör-3 & 1576,1 & 58 & 3 & Operatör-3 & 1599,9 \\
\hline 29 & 1 & Operatör-3 & 1548,5 & 59 & 5 & Operatör-3 & 1524,7 \\
\hline 30 & 9 & Operatör-3 & 1638 & 60 & 2 & Operatör-3 & 1576,3 \\
\hline
\end{tabular}

Tablo 3'te varyansa bağlı Gage R\&R analizi sonuçları gösterilmektedir. Tablo 3 incelendiğinde toplam değişkenliğin \%1,34'ünün ölçüm sisteminin değişkenliğinden \%98,66'sının ise parça değişkenliğinden kaynaklandığı görülmektedir. Parçadan kaynaklı değişkenliğin toplam değişkenliğe katkısının yüksek olması ölçüm sisteminin parçaları güvenilir 
bir şekilde ayırt ettiğini göstermektedir. Ölçüm sisteminin değişkenliğinin $\% 1,24$ 'ü tekrar üretilebilirlikten, $\% 0,10$ 'u ise tekrar edilebilirlikten kaynaklanmaktadır. Tekrar üretilebilirlikten kaynaklanan değişkenliğin, tekrar edilebilirlikten kaynaklanan değişkenlikten daha fazla olduğu görülmektedir. Bu durum ölçüm sisteminden kaynaklanan değişkenliğin \%1,24'ünün operatörden kaynaklı olduğunu, ölçüm cihazından kaynaklanan değişkenliğin ise \%0,10 olduğunu göstermektedir. Denklem 1'de ifade edildiği gibi Tablo 3'te toplam değişkenliğin varyansı, "Gage" olarak adlandırılan ölçüm sisteminden kaynaklanan değişkenliğin varyansı ile parçadan kaynaklanan değişkenliğin varyansının toplamına eşittir. Denklem 2'de gösterildiği gibi Tablo 3'te ölçüm sisteminden kaynaklanan değişkenliğin varyansının, tekrar edilebilirlik ve tekrar üretilebilirlik bileşenlerinin varyansları toplamına eşit olduğu görülmektedir. Denklem 3 'te ifade edildiği gibi tekrar üretilebilirlikten kaynaklanan değişkenliğin varyansı, operatörden kaynaklanan değişkenliğin varyansı ile operatör parça etkileşiminden kaynaklanan değişkenliğin varyansı toplamına eşittir. Tablo 3'teki tekrar üretilebilirlik ve operatör ifadelerinin varyanslarının eşit olması operatör parça etkileşiminden kaynaklanan bir değişkenlik olmadığını göstermektedir.

Tablo 3.

Varyansa Bağlı Minitab Gage R\&R Analiz Sonucu

\begin{tabular}{lrr}
\hline & $\begin{array}{c}\text { Bileşen } \\
\text { Varyansı }\end{array}$ & $\begin{array}{c}\text { \% Katk1 } \\
\text { (Bileşen } \\
\text { Varyansı) }\end{array}$ \\
\hline Toplam Gage R\&R & 15,5835 & 1,34 \\
Tekrar edilebilirlik & 1,1413 & 0,10 \\
Tekrar üretilebilirlik & 14,4423 & 1,24 \\
Operatör & 14,4423 & 1,24 \\
Parça-Parça & 1150,6342 & 98,66 \\
Toplam Değişkenlik & 1166,2177 & 100,00 \\
\hline
\end{tabular}

Tablo 4'te standart sapmaya bağlı Gage R\&R analizi sonuçları gösterilmektedir. Bu tabloda yer alan ve ölçüm sisteminin yeterliliğini analiz etmek için kullanılan göstergelere bakıldığında \%R\&R değerinin 11,56 olduğu görülmektedir. Bu değer toplam sistem değişkenliğinin yüzde 11,56'sının ölçüm sisteminden kaynaklandığ 1 anlamına gelmektedir. Analiz sonucunda elde edilen \%R\&R değerinin literatürde yer alan kabul edilebilir aralıkta yer alması, ölçüm sisteminin yeterliliğinin kabul edilebilir düzeyde olduğunu göstermektedir. \%P/T değerinin 9,87 çıkması, ölçüm sisteminden kaynaklanan değişkenliğin parça değişkenliğini ölçebilmesi için istenilen düzeyde olduğunu göstermektedir. Analiz sonucunda farklı kategori sayısı
Programlanabilir

Güç Cihazının Ölçüm

Yeterliliğinin

Gage R\&R İle

Analiz Edilmesi 
İşletme Bilimi Dergisi (JOBS), 2020; 8(3): 427-447. DOI: 10.22139/jobs.762798

Programlanabilir

Güç Cihazının Ölçüm

Yeterliliğinin

Gage R\&R İle Analiz Edilmesi

440 olarak da ifade edilen SNR değeri 12 olarak elde edilmiştir. Bu değerin 5 veya daha büyük olması ölçüm sisteminin parça değişkenliğini ölçebilecek yeterlilikte olduğunu göstermektedir.

Tablo 4.

Standart Sapmaya Bağlı Minitab Gage R\&R Analiz Sonucu

\begin{tabular}{lrrrr}
\hline & & & & \\
& Standart Sapma & $6 \times \mathrm{SD}$ & \%R\&R & $\% \mathrm{P} / \mathrm{T}$ \\
\hline Toplam Gage R\&R & 3,9476 & 23,686 & 11,56 & 9,87 \\
Tekrar edilebilirlik & 1,0683 & 6,41 & 3,13 & 2,67 \\
Tekrar üretilebilirlik & 3,8003 & 22,802 & 11,13 & 9,5 \\
Operatör & 3,8003 & 22,802 & 11,13 & 9,5 \\
Parça-Parça & 33,921 & 203,526 & 99,33 & 84,8 \\
Toplam Değişkenlik & 34,15 & 204,9 & 100 & 85,37 \\
\hline
\end{tabular}

Şekil 2'de sistemdeki bileşenlerin varyansları gösterilmektedir. Grafik incelendiğinde toplam varyansın \%1,34'ü ölçüm sisteminin değişkenliğinden \%98,66'sı ise parça değişkenliğinden oluşmaktadır. Ölçüm sisteminin değişkenliğinin $\% 1,24^{\prime} \ddot{\mathrm{u}}$ tekrar üretilebilirlikten, $\% 0,10^{\prime} \mathrm{u}$ ise tekrar edilebilirlikten kaynaklanmaktadır.

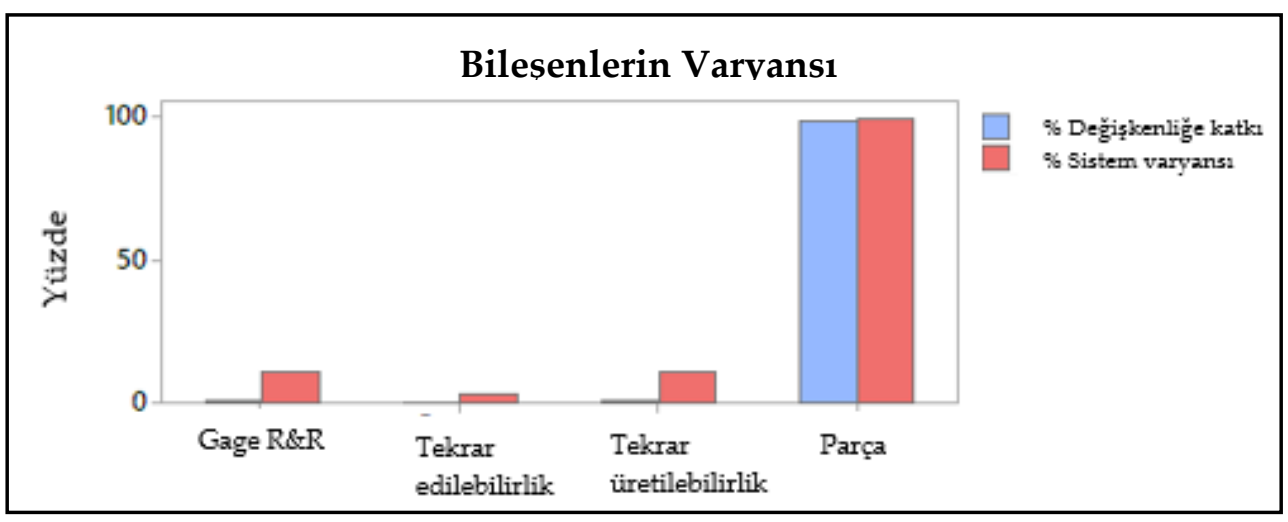

Şekil 2.

Sistemdeki Değişkenliğin Dağılımı

Şekil 3'te operatör ölçümlerinin R grafiği gösterilmektedir. Operatör ölçümleri arasındaki farkın sınırlar içerisinde kalması ölçümlerinin tutarlı olduğunu göstermektedir. $\mathrm{R}$ grafiği incelendiğinde Operatör-2'nin birinci ölçümünün ve Operatör-3'ün ise altıncı ölçümünün sınırlar dışarısında kaldığ 1 görülmektedir. Bu durum operatörlerin ölçüm sırasında çevresel faktörlerden etkilenmiş olabileceğini ya da ölçümleri yaparken bir hata yapmış olabileceğini göstermektedir. 


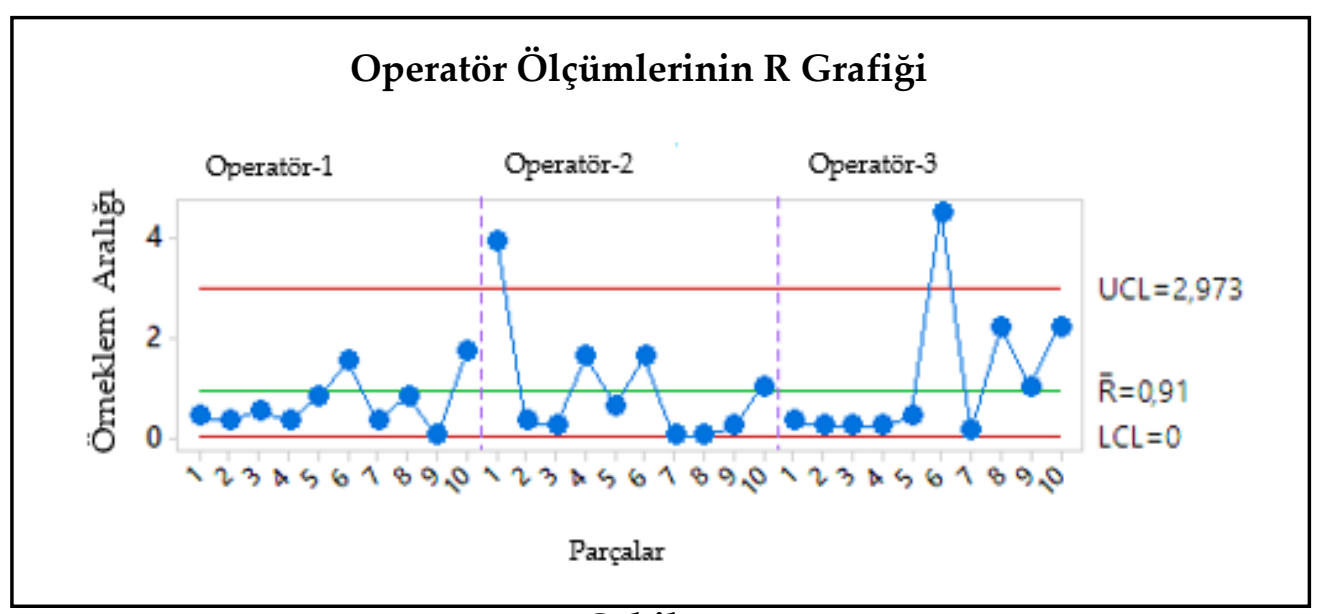

Programlanabilir

Güç Cihazının

Ölçüm

Yeterliliğinin

Gage R\&R İle

Analiz Edilmesi

Şekil 4 'te operatörlerin ölçümlerinin $\bar{X}$ grafiği yer almaktadır. Bu grafik her operatörün her parçadaki ölçümlerinin ortalamaları ile oluşturulmaktadır ve parçaların rassallığı hakkında bilgi vermektedir. Limitlerin dışındaki parçaların varlığı numunelerin rassal seçildiğini göstermektedir. İyi bir ölçüm sistemi için ölçümlerin kontrol dışında olması gerekmektedir. Ölçümlerin kontrol dışında olması, parçadan kaynaklanan değişkenliğin ölçüm sisteminden kaynaklanan değişkenlikten daha fazla olduğunu ifade etmektedir. Grafikte ortalama değeri $\bar{X}=1573,5^{\prime}$ tir. Üst limit $U C L=1575,3$ iken alt limit değeri $L C L=1571,8^{\prime}$ dir. Grafik incelendiğinde sadece Operatör-1'in 2.parça için yaptığ1 ölçümlerin ortalaması kontrol limitleri arasında yer almaktadır. Bu noktanın dışında, diğer operatörlerin her parça için yaptığı ölçümlerin ortalamasının kontrol limitlerinin dışarısında olduğu görülmektedir. Bu durum ölçüm sisteminin yeterli olduğunu göstermektedir.

\section{Operatör Ölçümlerinin $\bar{X}$ Grafiği}

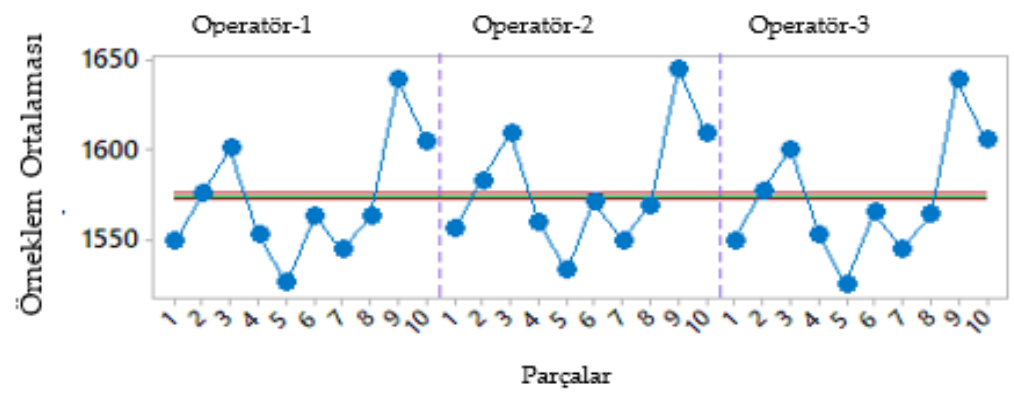

Şekil 4.

$\bar{X}$ Grafiği 
Programlanabilir

Güç Cihazının Ölçüm

Yeterliliğinin

Gage R\&R İle Analiz Edilmesi

442
Şekil 5'te operatörlerin ölçümlerinin box-plot grafiği yer almaktadır. $\mathrm{Bu}$ grafikte her operatörün tüm ölçümlerinin ortalaması ve ortalamalar arasında bir çizgi gösterilmektedir. Diyagramlar arasındaki çizginin yatay olması her operatör için ortalama ölçümlerin benzer olduğunu göstermektedir. Grafikte Operatör-2'nin ölçümlerinin diğerlerine göre daha yüksek olduğu görülmektedir. Bu durumun sebebi araştırıldığında bu operatörün ölçümlerini diğer operatörlere göre daha uzun sürede yaptığ 1 anlaşılmıştır.

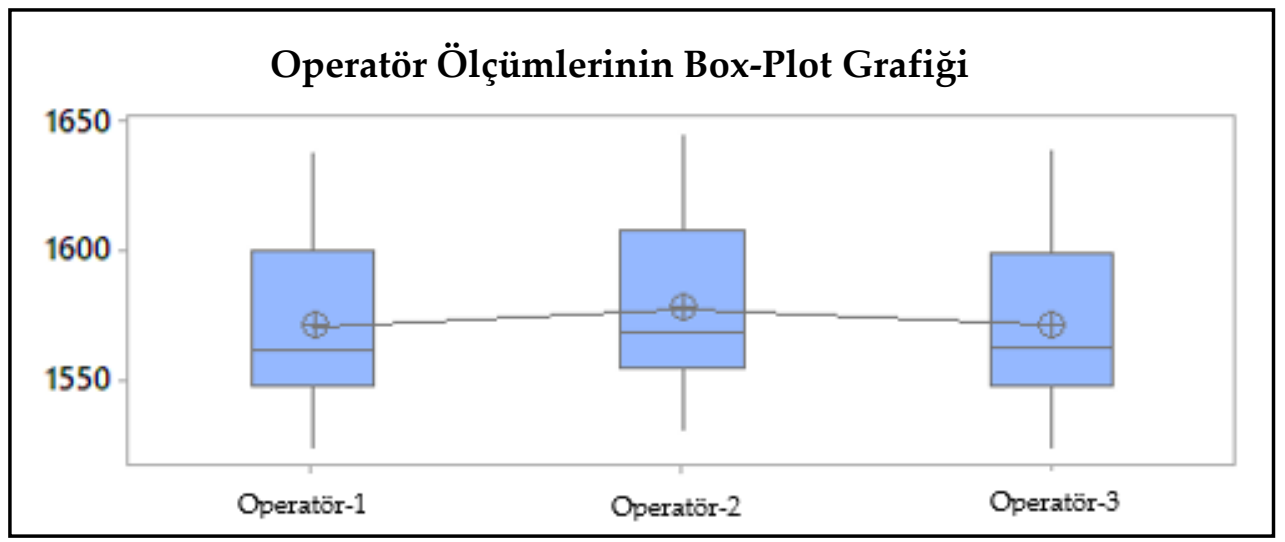

Şekil 5.

\section{Operatör Ölçümlerinin Box-Plot Grafiği}

Şekil 6'da operatör ve parça arasındaki etkileşimi gösterilmektedir. Tüm operatörler için çizginin paralel olması, operatörlerin parçadan etkilenmediğini göstermektedir.

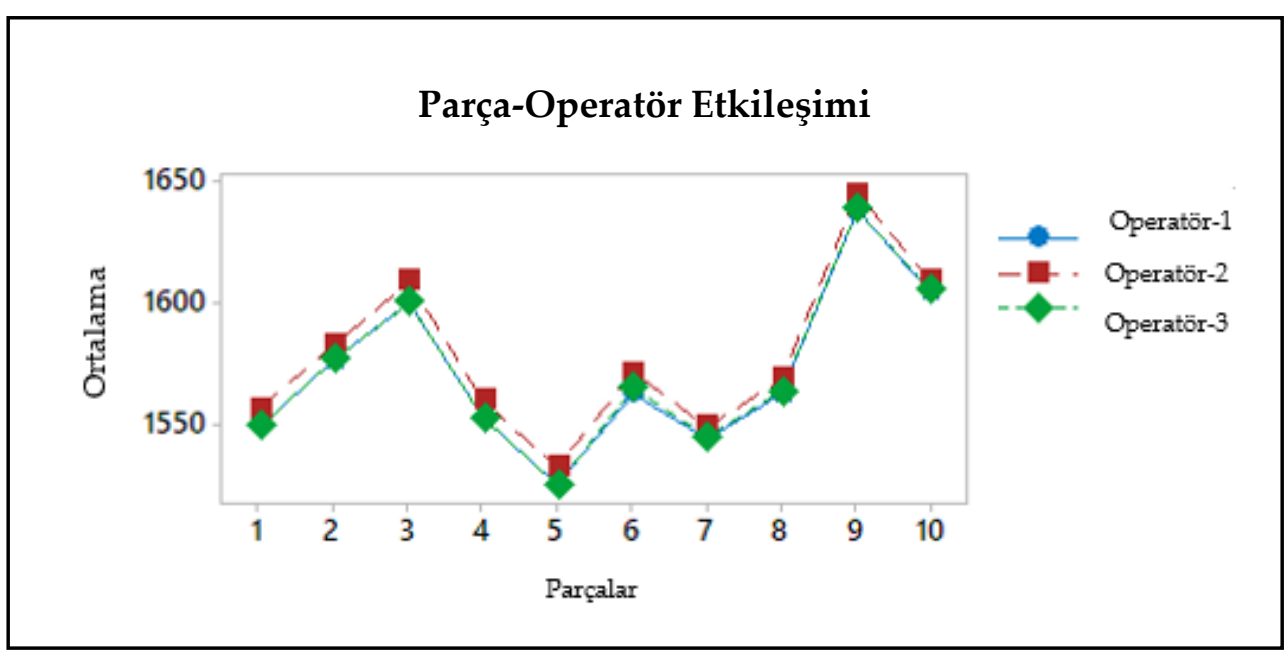

Şekil 6.

Parça-operatör Etkileşimi 


\section{SONUÇ ve ÖNERİLER}

Teknolojinin gelişmesiyle birlikte artan rekabet ortamında işletmeler varlıklarını sürdürebilmek için hatalı ürün üretimini sıfıra indirmeye yönelik çalışmalar yapmaya başlamıştır. Ürünün hatalı olup olmadığının değerlendirilebilmesi için kullanılan ölçüm sisteminin yeterli olması gerekmektedir. Bu sebeple ölçüm sisteminin yeterliliğinin belirlenmesi kalite iyileştirme çalışmaları için önemli bir unsurdur. Bu durum ölçüm sisteminin yeterli olup olmadığının nasıl belirlenmesi gerektiği problemini ortaya çıkarmıştır.

Parçaların farklı operatörler tarafından farklı zaman dilimlerinde ölçülmesi için kullanılan ölçüm sisteminin operatörlerden ya da zamandan kaynaklanan değişkenliğini ifade etmek için kullanılan tekrar üretilebilirlik, aynı parça için aynı operatör ve aynı zaman dilimlerinde ölçüm yapıldığında sistemden ya da ölçüm cihazından kaynaklanan değişkenliği ifade etmek için kullanılan tekrar edilebilirlik olmak üzere iki bileşeni bulunmaktadır. Sistemin tekrar edilebilirliği ve tekrar üretilebilirliği Gage R\&R şeklinde ifade edilmektedir. Ölçüm sistemlerini değerlendirmek için kullanılan Gage R\&R çalışmalarında sistemi analiz etmek ve değişkenlik bileşenlerini tahmin etmek için iki yönlü ANOVA kullanımı oldukça yaygındır (Al-Refaie \& Bata, 2010).

Bu çalışmada beyaz eşya sektöründe faaliyet gösteren bir firmanın güvenlik laboratuvarındaki programlanabilir güç kaynağı cihazının TS EN 60335-1 standardına göre çay makinesi güç ölçümü için yeterliliği Gage R\&R yöntemi ile analiz edilmiştir. Literatürde bu konuyla ilgili yapılan çalışmalar incelenerek 3 operatör, 10 adet parça ve 2 kez ölçümden oluşan toplamda 60 veri noktası kullanılmıştır. ANOVA yöntemi kullanılarak bileşenlerin değişkenlikleri tahmin edilmiştir. Analizden elde edilen sonuçlar toplam değişkenliğin \%1,34'ünün ölçüm sisteminin değişkenliğinden \%98,66'sının ise parça değişkenliğinden kaynaklandığını göstermektedir. Ölçüm sisteminin değişkenliğinin \%1,24'ü tekrar üretilebilirlikten \%0,10’u ise tekrar edilebilirlikten kaynaklanmaktadır. Ölçüm sisteminin yeterliliğini değerlendirmek için literatürde bu konuyla ilgili yapılmış çalışmalarda da kullanılan \%R\&R, \%P/T ve Sinyal-gürültü oranı (SNR) değerleri ele alınmıştır. Yapılan değerlendirme sonucunda \%R\&R değeri 11,56; \%P/T değeri 9,87; SNR değeri ise 12 olarak elde edilmiştir. Bu değerler literatürde belirtilen istenilen değerlere sahip olduğundan ölçüm sisteminin çay makinesinin gücünü ölçmek için yeterli olduğunu söylemek mümkündür.

$\mathrm{Bu}$ çalışmada ele alınan konu ile ilgili gelecekte yapılacak çalışmalarda ölçüm sisteminin yeterliliğini analiz etmek için literatürdeki
Programlanabilir

Güç Cihazının

Ölçüm

Yeterliliğinin

Gage R\&R İle

Analiz Edilmesi 
İşletme Bilimi Dergisi (JOBS), 2020; 8(3): 427-447. DOI: 10.22139/jobs.762798

Programlanabilir

Güç Cihazının

Ölçüm

Yeterliliğinin

Gage R\&R İle

Analiz Edilmesi

444

çalışmalarda da yer alan MANOVA yöntemi kullanılarak uygulama tekrarlanabilir. $\mathrm{Bu}$ iki yöntemin etkinliğine yönelik karşılaştırmalar yapilabilir.

\section{KAYNAKÇA}

AIAG; Automative Industry Action Group. (2010). Measurement System Analysis.

AIAG; Automotive Industry Action Group. (2002). Measurement System Analysis, Third ed. Detroit, MI.

Al-Refaie, A., \& Bata, N. (2010). Evaluating measurement and process capabilities by GR\&R with four quality measures. Measurement, 43(6), 842-851. doi:10.1016/j.measurement.2010.02.016

Aquila, G., Peruchi, R. S., Junior, P. R., Rocha, L. S., Rodrigo de Queiroz, A., Pamplona, E., \& Balestrassi, P. P. (2018). Analysis of the wind average speed in different Brazilian states using the nested GR\&R measurement system. Measurement,115,217-222. doi: 10.1016/j.measurement.2017.10.048

Burdick, R. K., \& Larsen, G. A. (1997). Confidence intervals on measures of variability in R\&R studies. Journal of Quality Technology, 29, 261-273. doi: 10.1080/00224065.1997.11979768

Burdick, R. K., Borror, C. M., \& Montgomery, D. C. (2003). A Review of Methods for Measurement Systems Capability Analysis. Journal of Quality Technology, 35(4), 342-354. doi: /10.1080/00224065.2003.11980232

Erdmann, T. P., Does, R., \& Bisgaard, S. (2009). Quality Quandaries*: A Gage R\&R Study in a Hospital. Quality Engineering, 22(1), 46-53. doi:10.1080/08982110903412924

Gao, Z., Moore, T., Smith, A., Doub, W., Westenberger, B., \& Buhse, L. (2007). Gauge Repeatability and Reproducibility for Accessing Variability During Dissolution Testing: A Technical Note. AAPS PharmSciTech, 8(4),11-15.

Lin, C.-Y., Hong , C.-L., \& Lai , J.-Y. (1997). Improvement of A Dimensional Measurement Process Using Taguchi Robust Designs. Quality Engineering, 9(4), 561-573. doi:10.1080/08982119708919078

Majeske, K. D. (2008). Approval criteria for multivariate measurement systems. Journal of Quality Technology, 40, 140-153. doi:/10.1080/00224065.2008.11917721

Minitab. (2017, May1s 1). Quality Magazine. https://www.qualitymag.com/articles/93931-gage-rr-are-10-parts-3operators-and-2-replicates-enough (Erişim Tarihi: 23 Mayıs 2020).

Peruchi, R. S., Balestrassi, P. P., Anderson, P., Ferreira, J. R., \& Carmelossi, M. (2013). A new multivariate gage $R \& R$ method for correlated characteristics. 
International Journal of Production Economics, 144(1), 301-315. doi: 10.1016/j.ijpe.2013.02.018

Vardeman, S., \& VanValkenburg, E. (1999). Two-Way Random-Effects Analyses and Gauge R\&R Studies. Technometrics, 41(3), 202-211. doi: 10.1080/00401706.1999.10485669

Wrzochal, M., \& Adamczak, S. (2019). Application of a Gage R\&R study in evaluation of rolling bearing measurement system accuracy. Transportation Research Procedia, 934-939. doi:10.1016/j.trpro.2019.07.131
Programlanabilir Güç Cihazının Ölçüm Yeterliliğinin Gage R\&R İle Analiz Edilmesi

\section{MEASURING QUALIFICATION OF THE PROGRAMMABLE POWER DEVICE BY GAGE R\&R ANALYSIS EXTENDED ABSTRACT}

One of the aims of quality improvement studies is to reduce variability and reduce the production of defective products to zero. When a product is found to be unsuitable, variability is often associated with the process and therefore improvements are made to increase process capability. Although the process followed is correct, efforts made for improvement can be fruitless due to the insufficiency of the measurement system. In cases where the measurement system is sufficient, errors made while measuring can be at an unacceptable level when compared with process variability. For this reason, it is necessary to examine the variability of a measurement system or production process before improvement studies. This situation has revealed the problem of how to determine whether the measurement system is sufficient or not. If a measurement system is to be used, this must first be verified. Because it is possible to determine whether the measurements are within the tolerances only with the presence of an adequate measurement system. The purpose of Gage R\&R is to determine the variability arising from the measurement system and to separate it from the system variability to reveal the main process variability. The main reason for this decomposition is that the total variability is due to both the process variability and the measurement system. The variability of the measuring system consists of two components, repeatability and reproducibility. Repeatability refers to the variability caused by the system or the measuring device when the same part is measured by the same operator and at the same time intervals. Reproducibility refers to the variability arising from operators or time. The repeatability and reproducibility of the system is expressed in the form of Gage R\&R. 
Programlanabilir

Güç Cihazının

Ölçüm

Yeterliliğinin

Gage R\&R İle Analiz Edilmesi

446
In the literature, there are studies on this subject in different fields. Gao et al. (2007) used Gage R\&R to examine the variability of dissolution test measurement systems in the pharmaceutical industry due to apparatus, operator, and tablets. Erdman et al. (2010) evaluated the body temperature measurements made by nurses with ear thermometers in line with the principles of Gage R\&R analysis in their study in the health sector. Aquila et al. (2018) aimed to evaluate the average wind speed behavior in four main wind energy generating states in Brazil using the Gage R\&R method. The purpose of Gage $R \& R$ is to determine the variability arising from the measurement system and to separate it from the system variability to reveal the main process variability. One of the methods used for Gage $R \& R$ analysis is the Average\&Range ( $A \& R)$ method. It is used when the number of repetitions is two or three to estimate the repeatability and reproducibility of measurement systems $\bar{X}$ graph and $\mathrm{R}$ graph are used to determine the variability of the measurement system. Another Gage R\&R method used in this study is the Analysis of Variance (ANOVA) method. The purpose of this method is to separate the maximum variability of the measuring system into change caused by the part being measured and the change caused by the measuring system. In the initial phase of a measuring device or bench; evaluating a new operator; after instrument calibration or when it is suspected that the measuring system is not sensitive enough in terms of tolerances, the ANOVA method is used. The difference of the ANOVA method from the A\&R method is that it also takes the part-operator interaction into account while evaluating the measurement system.

In some studies in the literature, different methods have been used to evaluate measurement systems. Lin et al. (1997) used the Taguchi method to reduce measurement variability. In addition, in this study, improvements were verified by conducting a Gage $R \& R$ study, process capability analysis was used to show the reduction effect on product variability. In the study conducted by Majeske (2008), the Multiple Variance Analysis method (MANOVA) was used to estimate the variance-covariance matrix for onefactor, two-factor and three-factor measurement systems.

In this study, the adequacy of the programmable power supply device in the security laboratory of a company operating in the white goods sector for tea machine power measurement according to the TS EN 60335-1 standard was analyzed using the Gage R\&R method. The aim of this study is to determine the variations in the measuring system and the programmable power device, and to determine whether the power of the measuring system is sufficient to determine that they meet the desired standards. The power measurements were made 2 times in different time periods by 3 operators for 10 tea 
machines produced by the company. In order to solve the problem of determining the adequacy of the measurement system, analyzes are made using different methods. In this study, ANOVA method was used for Gage $\mathrm{R} \& \mathrm{R}$ analysis. To evaluate the acceptability of the measurement system, $\% R \& R$, which is one of the indicators commonly used, $\% \mathrm{P} / \mathrm{T}$, which expresses the ratio of the sensitivity of the measurement system to the total tolerance as a percentage, and the Signal-to-Noise Ratio (SNR) values, which is one of the indicators of the quality of the measurement system, were discussed. The results obtained from the analysis show that $1.34 \%$ of the total variability is caused by the variability of the measurement system and $98.66 \%$ is due to the part variability. $1.24 \%$ of the variability of the measurement system is due to reproducibility and $0.10 \%$ from repeatability. According to the results obtained from the analysis, the $\% R \& R$ value is 11.56 ; $\% \mathrm{P} / \mathrm{T}$ value 9.87 ; SNR value was obtained as 12 . The $\% \mathrm{R} \& \mathrm{R}$ value means that 11.56 percent of the total system variability is caused by the measurement system. The fact that $\% \mathrm{P} / \mathrm{T}$ value is 9.87 indicates that the variability arising from the measurement system is at the desired level in order to measure the part variability. If the SNR value is 5 or more, it indicates that the measuring system is sufficient to measure the part variability. As a result of the analysis the equality of variances of the reproducibility and the operator expressions each other shows that there is no variation arising from the operator part interaction. Since these values have the desired values stated in the literature, it is possible to say that the measuring system is sufficient to measure the power of the tea machine.
Programlanabilir

Güç Cihazının

Ölçüm

Yeterliliğinin

Gage R\&R İle

Analiz Edilmesi 